in children and adolescents. J Hypertens. 2016. № 34 (10). P. 1887-920. DOI: 10.1097/HJH.0000000000001039.

5. Edvardsson D., Baxter R., Corneliusson L. Advancing Long-Term Care Science Through Using Common Data Elements: Candidate Measures for Care Outcomes of Personhood, WellBeing, and Quality of Life. Gerontology \& Geriatric Medicine. 2019. Vol. 5, P. 1-15. DOI: 10.1177/2333721419842672.

DOI https://doi.org/10.30525/978-9934-26-182-4-16

\title{
ПОШКОДЖЕННЯ НЕЙРОНІВ ПРИ ПЕЧІНКОВІЙ ЕНЦЕФАЛОПАТІЇ
}

\author{
Рафальська Н. С. \\ заочний аспірант кафедри неврології \\ Харківський національний медичний університет \\ Товажнянська О. Л. \\ доктор медичних наук, професор, \\ завідувачка кафедри неврології \\ Харківський наиіональний медичний університет \\ Марковська О. В. \\ кандидат медичних наук, \\ доцент кафедри неврології \\ Харківський національний медичний університет \\ м. Харків, Україна
}

Печінкова енцефалопатія (ПЕ) - часте ускладнення та один 3 найважчих проявів захворювань печінки, що значно ускладнює життя пацієнтів та погіршує якість їхнього життя. ПЕ розвивається на тлі багатьох відомих гострих і хронічних захворювань печінки, таких як вірусний гепатит, токсичний гепатит, хронічний активний гепатит, обтурація жовчних шляхів, цироз печінки та ін. [1,2]. Клінічна картина ПЕ представлена широким спектром неспецифічних неврологічних та психіатричних проявів, тяжкість яких прогресуюче наростає від мінімального ступеня до тяжкого ступеня згідно з критеріями West-Haven. При латентній ПЕ клінічна картина мінімальна, а достовірно змінюються лише результати психометричних тестів та електрофізіологічних 64 
функціональних тестів мозку $[3,5,6]$. При цьому навіть мінімальна ПЕ негативно впливає на здоров'я пацієнта і є фактором ризику розвитку тяжких форм ПЕ, що обумовлює необхідність ії своєчасної діагностики $[3,4,5,6]$. В останні роки при захворюваннях, пов'язаних з безпосереднім ураженням нервової тканини, цінну інформацію про ступінь ушкодження нейронів та порушення проникності нейрогематичного бар'єру надає визначення рівнів нейрон-специфічних білків у біологічних рідинах [10]. Надійним критерієм нейрональної деструкції $є$ визначення вмісту нейронспецифічної енолази (NSE) [7]. У ряді досліджень описано підвищення концентрації NSE при травмах головного та спинного мозку, інсультах, менінгітах, діабеті, епілепсії [7-10].

Метою дослідження було оцінити ступінь нейронального пошкодження за рівнем нейрон-специфічної енолазив крові хворих на печінкову енцефалопатію та встановити йогороль в розвитку захворювання.

Було обстежено 95 пацієнтів 3 печінковою енцефалопатією, обумовленою хронічним гепатитом (48 хворий, з яких 21 чоловіків й 23 жінки) та цирозом печінки (47 пацієнтів, з яких 27 чоловіків й 20 жінок). Вік пацієнтів становив 51,2 \pm 7,6 років. Всі хворі пройшли ретельне соматичне, неврологічне, нейропсихологічне (тест зв'язку чисел ТЗЧ, Монреальська шкала оцінки пізнавальних функцій (Шкала МоCA), госпітальна шкала тривоги і депресії HADS), інструментальне та біохімічне обстеження, на підставі яких було підтверджено діагнози хронічного гепатиту й цирозу печінки, а також встановлена стадія ПЕ згідно критеріїв West-Haven [2-4]. Контрольну групу склали 30 умовно здорових осіб відповідної статі та віку.

Визначення рівню нейрон-специфічної енолази проводили за допомогою твердофазного імуноферментного аналізу (набір реагентів NSEIФА-БЕСТ) на імуноферментному напівавтоматичному аналізаторі STAT FAX (США). Визначення вмісту аміаку у крові проводили за допомогою спектрофотометричного методу на біохімічному напівавтоматичному аналізаторі STAT FAX 303+ (США). Статистична обробка отриманих результатів була проведена за допомогою комп'ютерної програми Statistica 6. Розраховувалися середні значення показників та помилки середніх. В якості критерію значущості відмінності вибір використовувався параметричний критерій Стьюдента. Відмінності приймалися за достовірні при $\mathrm{p}<0,05$. Для встановлення наявності та визначення сили і спрямованості ймовірного зв'язку між показниками проводили кореляційний аналіз із застосуванням коефіцієнта Пірсона (r). Розходженнявважалистатистичнозначущим при $(\mathrm{p}<0,05)$. 
Згідноотриманихрезультатівсередхвориху 19осіб (20 \%) булодіагностованолатентну ПЕ, у 33осіб (37,7 \%) - ПЕ Істадії і у 43 пацієнтів $(45,3 \%)$ - ПЕ ІІстадії. Основнимипроявами ПЕ при ХГ та ЦП були когнітивні порушення, дисомнічні розлади, астенічний синдром та порушеннядрібної моторики, на якіслідзвертатиувагуу першучергу при обстеженіхворихіззахворюваннями печінки в рутиннійклінічнійпрактиці для ранньоїдіагностики ПЕ, навіть на латентнійстадії.Психометричне тестування визначило зниження загального балу за шкалою МоСА до $26,1 \pm 0,9$ балів; 23,1 $\pm 2,9$ балів; $18,4 \pm 3,1$ балів при латентній, I та II стадіях ПЕ відповідно (контроль $-28,2 \pm 0,8$ балів); збільшення часу виконання ТЗЧ до 40,3 $\pm 3,5$ c; 49,9 \pm 7,2 c; 75,7 $\pm 9,3$ с. балів при латентній, I та II стадіях ПЕ відповідно (контроль - 29,2 $\pm 0,6$ с); підвищення загального балуза шкалою HADSдо8,04 $\pm 1,8$ балів, 8,42 $\pm 1,9$ балів та $13,2 \pm 3,5$ балів при латентній, I та II стадіях ПЕ відповідно(контроль $3,63 \pm 0,72)$. Отримані дані підтверджували той факт, що когнітивні та психоемоційні розладі $є$ аблігатними синдромами на всіх стадіях ПЕ, навіть на латентній стадії.

Аналіз отриманих біохімічних даних визначив збільшення рівню аміаку в сироватці крові до 16,64 \pm 4,18 мкмоль/л; $21,27 \pm 9,38$ мкмоль/л; $26,68 \pm 3,72$ мкмоль/л у хворих на латентну, I та II стадії ПЕ відповідно (контроль - 10,31 $\pm 2,07$ мкмоль/л)та підвищення вмісту нейрон-специфічної енолази до19,39 \pm 5,24 нг/мл, 25,42 \pm 9,33 нг/мл, 27,36 $\pm 3,25$ нг/мл, при латентній, I та II стадіях ПЕ відповідно (контроль - 10,56 $\pm 2,38$ нг/мл).

Проведений кореляційний аналіз визначив вірогідний $(\mathrm{p}<0,05)$ зворотний зв'язок слабкої сили між підвищенням концентрації NSE та зниженням загального балу МоСА $(\mathrm{r}=-0,21)$, вірогідний $(\mathrm{p}<0,05)$ прямий зв'язок слабкої сили між підвищенням концентрації NSE та підвищенням загального балу за Госпітальної школою тривоги та депресії HADS $(\mathrm{r}=+0,30)$. Це свідчило про роль нейронального пошкодження (за даними підвищення вмісту NSE в сироватці крові) у розвитку та прогресуванні когнітивних та психоемоційних порушень при ПЕ у хворих на ПЕ.

Узагальнюючи отримані дані, було визначене збільшення вмісту аміаку та концентрації NSE в сироватці крові у міру прогресування стадії тяжкості ПЕ,а також зворотний зв'язок між маркером нейронального пошкодження NSE та когнітивною дисфункцією й психоемоційними порушеннями у хворих на ПЕ. Отримані дані дозволяють розцінювати NSE як ранній маркер пошкодження нейрональної тканини при захворюваннях печінки й додатковий критерій тяжкості ПЕ. 


\section{Література:}

1. Циммерман Я.С. Печеночная энцефалопатия: дефиниция, этиология, факторы патогенеза, клиника, методы диагностики и лечения. Клиническая гепатология. 2017. № 2. С. 68-73.

2. Wijdicks E.F. Hepatic encephalopathy. E.F. Wijdicks, N Engl J Med. 2016. Vol. 375(17). P. 1660-1670. https://doi.org/10.1056/nejmra1600561 (дата звернення: 27.10.2016).

3. В.I. Денисюк, О.В. Денисюк. Цироз печінки: стандарти діагностики та лікування 3 урахуванням рекомендацій доказової медицини. Гострі та невідкладні стани у практиці лікаря. 2012. № 2-3 (31): https://urgent.com.ua/ua-issue-article-428 (дата звернення: 21.05.2012).

4. Grover V.P., Tognar elli J.M., Massie N., Crossey M.M., Cook N.A., Taylor-Robinson S.D. The why and where fore of hepatic encephalopathy. Int J Gen Med. 2015. Vol. 8. P. 381-390.

5. Smith A. Symbol Digit Modalities Test (SDMT) A. Smith Neuropsychological Assesment. - 3th ed. / Ed. By M. Lezak. - NewYork: Oxford University Press, 1982. - P. 379-381.

6. Randolph C., Hilsabeck R., Kato A., Kharbanda P., Li Y.Y., Mapelli D. Neuropsychological assessment of hepatic encephalopathy: ISHEN practice guidelines Liver Int. - 2009. -Vol. 29. - P. 629635.

7. Евлашева О.О., Астахин А.В., Левитан Б.Н. Маркеры нейродеструкции (общий белок миелина и нейронспецифическая енолаза) при хронической печеночной энцефалопатии. Современные проблемы науки и образования. -2015 . - № 3 .

8. Антонова О.М. Нейроспецифическая енолаза и ее роль в механизм ахантительной агрессии в мозг: Дис. докт. мед. наук. - М.; 1997. Antonova OM. Neyrospetsificheskaya enolaza i eerol' v mekhanizmak hantitel'noyagressii v mozg [dissertation]. Moscow; 1997. (InRuss).

9. Pypa V., Svistilnik R. V., Moskovko G. S., Lysytsia Yu. M., Murhina M. M. Neuron specific enolase as a possible indicator of neuron damage in children with acute meningitis. Запорожский медицинский журнал. Том 20, No 3(108), C. 354-358.

10. Пуголовкин К.А., Домбровская Е.А. Показатели нейронспецифической енолазы и белка S100 в крови при некоторых формах симптоматической эпилепсии у детей как отражение дисрегуляционной патологии центральной нервной системы. Consilium Medicum. 2017; 19 (2.3. Neurology and rheumatology). C. 23-27. 